\title{
LATE-SOWN LENTIL PERFORMANCE IN RESPONSE TO FOLIAR APPLICATION OF ZINC
}

\author{
Anil Kumar SingH* AND BP Bhatt \\ ICAR Research Complex for Eastern Region Patna-800 014, India
}

Key words: Foliar application, Zinc, Growth, Seed development, Late-sown lentil

\begin{abstract}
Highest and lowest plant height at harvest was recorded with application of $0.08 \% \mathrm{Zn}$ and in control treatment, respectively. Longest and shortest roots were recorded in the plots treated with $0.08 \% \mathrm{Zn}$ and control respectively. Zn treatment of $0.04 \%$ produced maximum lentil seed whereas lowest was recorded under control.
\end{abstract}

India is world largest homeland of vegetarian population and world leader in pulses production and import to provide protean supplements (Ali and Gupta 2012). Lentil (Lens culinaris Medik.) is one of the most nutritious cool season food legumes and ranks next only to chickpea. It is one of the prominent sources of vegetable protein in the Indo-Gangetic plain (IGP) region, essentially grown as a rainfed crop on the residual soil moisture of preceding crop (rice in general) (Ali et al. 2012 and Joshi 1998). Zn deficiency is wide spread and very common in IGP, in the rice growing tract in general and rice-wheat and rice-lentil cropping system in particular (Joshi 1998 and Ali et al. 2012). Role of zinc is as multifaceted as the interface that reduces its availability. Physiologically its role in a plant is either as a metal constituent in an enzymes or as a functional co-factor of number of enzymes reactions. In general zinc deficient plant show signs of low levels of auxins such as IAA. It is required for synthesis of IAA (Guilfoyle and Hagen 2001 and Liscum and Reed 2002). After flowering, high concentration of zinc in plant will enhance cell differentiation. Zinc plays a greater role during reproductive phase especially during fertilization.

Remarkably pollen grain contains zinc in very high quantity. At the time of fertilization most of zinc is diverted to seed only (Jenik and Barton 2005, Pandey and Gautam 2009 and Reid et al. 2011). Foregone discussion outlined the role and importance of zinc in lentil crop production particularly under late sown conditions. This field experiment was undertaken, keeping in view the importance of zinc especially during sensitive phase may boost the performance of late sown lentil in the IGP region of India; with an objective to improve the lentil productivity and production by foliar supplementing of zinc to correlate and validate critical phase.

To evolve zinc management scheme, a field experiment was conducted at ICAR Research Complex for Eastern Region Patna during 2008-09 and 2009-10 in randomized block design (RBD) and replicated thrice. The experimental plot size was $10.0 \mathrm{~m} \times 5.0 \mathrm{~m}$. The experiment consist of 4 treatments (concentration levels) of $\mathrm{Zn}$, namely (control) $\mathrm{Zn}_{1}(0.0 \%), \mathrm{Zn}_{2}(0.02 \%), \mathrm{Zn}_{3}$ $(0.04 \%), \mathrm{Zn}_{4}(0.08 \%)$. Foliar applications were carried out at pre-flowering and post podding stages.

Every time, light irrigations were provided two days before the treatment applied. The chosen agrochemical was none other than commercial grade zinc sulphate $\left(\mathrm{Zn} \mathrm{SO}_{4} .7 \mathrm{H}_{2} \mathrm{O}\right)$ which contains $21 \% \mathrm{Zn}$ (active ingredient). Long duration (145 to 155 days) genotype Swarna Mansoori "MTU7029" was chosen for rice crop. Tested lentil genotype was Pant Lentil 406 (PL-406), recommended for North and Eastern zone i.e. Indian IGP, where this field experiment was

*Author for correspondence: <anil.icarpat@gmail.com>. 
Conducted, as well as its performance even under late sown condition along with its medium maturity (125 - 135 days) are few features faovoured its selection. Sowing of lentil was performed on $10^{\text {th }}$ of December during both occasions. Seeds were sown at $3 \mathrm{~cm}$ depth at $30 \mathrm{~cm}$ row distance. Nutrients particularly, nitrogen, phosphorus, potassium and sulphur were applied as basal dose as well as other agronomic management practice was as per recommended practices and was kept similar for all the treatments. One hand weeding after three weeks of sowing was performed to maintain optimum plant population. Two watering was done at pre flowering stage and post podding stage. Plant protection measures were taken care to manage the biotic stress if any. To ascertain the extent and pattern of effective availability of $\mathrm{Zn}$ applied to the leaves of lentil crop. Treatment used was Zinc (0\%) control, $\left(\mathrm{Zn}_{1}\right)$ 0.02\% $\left(\mathrm{Zn}_{2}\right), 0.04 \%\left(\mathrm{Zn}_{3}\right)$ and $0.08 \%\left(\mathrm{Zn}_{4}\right)$.

Data on number and dry weight of nodules/plant were recorded 60 and 90 DAS by digging five plants from each plot. Five plants were sampled 90 DAS for measuring shoot dry weight. Dry weight of the nodules and shoots were recorded by drying samples in an oven at $60^{\circ} \mathrm{C}$ for $72 \mathrm{hrs}$. Similarly, chlorophyll contents were taken at 90 DAS. Chlorophyll contents were determined in young leaves (3rd to 4th leaf from the top by the method described by Lichtenthaler and Wellburn (1983). At harvest five representative samples of each plot were collected and biometrical data were recorded and computed for plant height,shoot dry weight, root length, root dry weight, productive branch/plant, pod/plant, seed yield. Similarly 100 -seed weight was also computed. Biomass and seed yield (kg/ha) were computed based on seed weight per plot and computed for ha. Seed yield were adjusted to $12 \%$ moisture.

The plant height of lentil is significantly influenced by different levels of $\mathrm{Zn}$ (Table 1). Maximum $(42.2 \mathrm{~cm})$ and minimum $(32.8 \mathrm{~cm})$ plant height was recorded at harvest, with $0.08 \% \mathrm{Zn}$ and control (0\%) application of Zn, respectively (Table 1$)$. Similar results were also observed earlier (Ali et al. 2012 and Singh et al. 2011). Lentil root length at harvest also follows the same

Table 1. Effects of foliar application of zinc on growth and development of lentil.

\begin{tabular}{lcccccccc}
\hline \multirow{3}{*}{ Treatments } & \multicolumn{3}{c}{ At harvest } & \multicolumn{2}{c}{$\begin{array}{c}\text { Nodules/plant } \\
\text { (no.) }\end{array}$} & \multicolumn{2}{c}{$\begin{array}{c}\text { Nodule dry wt. } \\
\text { (mg/plant) }\end{array}$} & $\begin{array}{c}\text { Chlorophyll content } \\
\text { at 90 DAS } \\
\end{array}$ \\
\cline { 2 - 7 } & $\begin{array}{c}\text { Plant } \\
\text { height } \\
\text { (cm) }\end{array}$ & $\begin{array}{c}\text { Root } \\
\text { length } \\
\text { (cm) }\end{array}$ & $\begin{array}{c}\text { Root dry } \\
\text { wt. } \\
\text { (g/plant) }\end{array}$ & $\begin{array}{c}60 \\
\text { DAS }\end{array}$ & $\begin{array}{c}90 \\
\text { DAS }\end{array}$ & $\begin{array}{c}60 \\
\text { DAS }\end{array}$ & $\begin{array}{c}90 \\
\text { DAS }\end{array}$ & $\begin{array}{c}\text { DAs wt. of } \\
\text { leaves) }\end{array}$ \\
\hline Control & 32.8 & 7.9 & 1.87 & & & & 30.9 & 1.962 \\
$\mathrm{Zn}_{1}(0.0 \%)$ & & & & 10.6 & 14.9 & 27.3 & & \\
$\mathrm{Zn}_{2}(0.02 \%)$ & 38.7 & 10.2 & 2.01 & 12.7 & 15.2 & 31.9 & 33.4 & 2.329 \\
$\mathrm{Zn}_{3}(0.04 \%)$ & 39.8 & 11.4 & 2.12 & 15.9 & 18.3 & 34.2 & 36.5 & 2.542 \\
$\mathrm{Zn}_{4}(0.08 \%)$ & 42.2 & 12.1 & 2.34 & 17.4 & 21.8 & 37.1 & 41.3 & 2.654 \\
$\mathrm{p}=0.05$ & 2.8 & 1.42 & 2.45 & 1.6 & 2.1 & 2.4 & 3.3 & 0.127 \\
\hline
\end{tabular}

Fashion, longest $(12.1 \mathrm{~cm})$ and shortest $(7.9 \mathrm{~cm})$ root was recorded with $0.08 \% \mathrm{Zn}$ and control application, respectively. Root dry weight did not fail to copy the pattern of response, as it was previously seen in case of root length. Highest root dry weight (2.45 g/plant) was noticed with $0.08 \% \mathrm{Zn}$ (Table 1). Similar finding were also recorded by Pandey and Gautam 2009. Nodules/plant was recorded at two stages at 30 days interval starting with 60 DAS (Table 1). With increase in $\mathrm{Zn}$ concentration and advancement of growth stage, number of nodule increased significantly. This result is supported by Reid et al. (2011) and Van and Hartley (2000). Maximum (21.8 nodules at 90 DAS) and minimum (10.6 nodules at 60 DAS) were recorded with application of $\mathrm{Zn}_{4}$ and control, respectively. Nodule dry weight (mg/plant) had shown alike trend as it was noticed in case of nodules count. Nodule dry weight was increased with the time and also 
influenced with incremental doses of Zn. Maximum (41.3 mg/plant at 90 DAS) and minimum (27.3 mg/plantat 60 DAS) were recorded with application of $\mathrm{Zn}_{4}(0.08 \%)$ and $\mathrm{Zn}_{1}(0.0 \%)$, respectively. Earlier similar results were recorded (Reid et al. 2011 and Singh et al. 2011). Chlorophyll contents were measured at 90 DAS, significant increase in chlorophyll with increase $\mathrm{Zn}$ concentration were recorded up to highest concentration, though, maximum percentage increased was noticed in case of $\mathrm{Zn}_{2}$ over $\mathrm{Zn}_{1}$. Similar finding was also reported by Pandey and Gautam 2009.

Shoot dry weight was increased with increasing concentration of foliar applied $\mathrm{Zn}$ mineral (Table 2). Minimum (3.23 g/plant) and maximum (4.37 g/plant) shoot dry weight was recorded with application of $\mathrm{Zn}_{1}(0.0 \%)$ and $\mathrm{Zn} 4(0.08 \%)$, respectively. Similar stimulation of shoot dry weight was observed (Van and Hartley, 2000, Singh et al. 2011, Somani 2008 and McVicar et al. 2010). Number of productive branches per plant is one of the primary yield contributing traits get influenced with both the tested nutrients. Productive branches per plant had been recorded minimum (14) with no application of zinc whereas maximum (17) was obtained in case of $\mathrm{Zn}_{3}$ (0.04\%). Similar results in case of number of branches were observed (Singh et al. 2011, Singh and Bhatt 2013 and Somani 2008). Similarly, pod/plant were maximum (63.8) in plots fertilized foliar by application with $\mathrm{Zn}_{4}$ 0.08\%) and minimum (45.9) with no application of zinc treatment. Identical results were observed by Pandey and Gautam 2009. Total above ground biomass was also gets influenced significantly with applied zinc. Maximum $(2942.1 \mathrm{~kg} / \mathrm{ha})$ and minimum ( $2537.5 \mathrm{~kg} / \mathrm{ha}$ ) above ground biomass was recorded with the $(0.08 \%)$ plot and $(0.0 \%)$ zinc (Table 2). Similar findings were recorded in few species (Pandey and Gautam 009 and Ramakrishna et al. 2000).

Table 2. Effects of foliar application of zinc on yield attributes and seed yield of lentil.

\begin{tabular}{lccccccc}
\hline Treatments & $\begin{array}{c}\text { Shoot dry weight } \\
\text { (g/plant) }\end{array}$ & $\begin{array}{c}\text { Branches/ } \\
\text { plant }\end{array}$ & $\begin{array}{c}\text { Pod / } \\
\text { plant }\end{array}$ & $\begin{array}{c}\text { Biomass } \\
(\mathrm{kg} / \mathrm{ha})\end{array}$ & $\begin{array}{c}\text { Seed yield } \\
(\mathrm{kg} / \mathrm{ha})\end{array}$ & $\begin{array}{c}\text { Harvest } \\
\text { Index }\end{array}$ & $\begin{array}{c}\text { 1000-grain } \\
\text { wt }(\mathrm{g})\end{array}$ \\
\hline $\mathrm{Con}$ trol & & & & & & & \\
$\mathrm{Zn}_{1}(0.0 \%)$ & 3.23 & 14 & 45.9 & 2537.5 & 1063.1 & 0.40 & 24.7 \\
$\mathrm{Zn}_{2}(0.02 \%)$ & 3.67 & 16 & 54.2 & 2825.6 & 1171.2 & 0.39 & 24.7 \\
$\mathrm{Zn}_{3}(0.04 \%)$ & 4.11 & 17 & 58.0 & 2902.6 & 1238.6 & 0.39 & 24.8 \\
$\mathrm{Zn}_{4}(0.08 \%)$ & 4.37 & 16 & 63.8 & 2942.1 & 1208.6 & 0.38 & 25.0 \\
$\mathrm{p}=0.05$ & 0.18 & 2.0 & 8.6 & 87.5 & 35.2 & $\mathrm{NS}$ & NS \\
\hline
\end{tabular}

Highest lentil seed yield (1238.6 kg/ha) was recorded with $(0.04 \%)$ Zn treatment whereas lowest yield (1015 k/ha) was noticed with no application of $(0.0 \%) \mathrm{Zn}$. 1000-gain weight (g) was not influenced by of the levels of $\mathrm{Zn}$ as it is genetic characters and in general not influenced by management practices. Singh et al.(2011) also reported similar result. Harvest Index is also not influenced by any of the given treatment and this might be due to character, highly associated with genetic makeup of the crop. Similar result was also reported (Singh et al. 2011 and Thiyagarajan et al. 2003).

It is concluded that foliar application of zinc improves lentil productivity. Foliar application of zinc $(0.04 \%)$ not only proved to be most beneficial but also economical for lentil production.

\section{Acknowledgements}

Soil and plant samples were analysis as per the scheduled programme at central laboratory facility of Institute i.e. ICAR Research Complex for Eastern Region, Patna. Contribution of Dr. LK Prasad, and Mr. MK Meena laboratory incharge, of respective period are duly acknowledged. 


\section{References}

Ali M and Gupta S 2012. Carrying capacity of Indian agriculture: Pulse crops. Cur. Sci. 102(6): 874-881.

Ali RI, Awan TH, Ahmad, MM, Saleem U. and Akhtar, M 2012. Diversification of rice-based cropping systems to improve soil fertility, sustainable productivity and economics. J. Animal \& Plant Sci. 22: 108-112

Guilfoyle T and Hagen G 2001. Auxin response factors. J. Plant Growth Regul. 10: 281-291.

Jenik Pablo D and Barton M Kathryn 2005. Surge and destroy: The role of auxin in plant embryogenesis. Development 132: 3577-3585.

Joshi PK 1998. Performance of grain legumes in The Indo-Gangetic Plain in residual effects of legumes in rice and wheat cropping systems of the Indo-Gangetic Plain. In: Legumes in rice and wheat cropping systems of the Indo-Gangetic plain. (Kumarrao, J.V.D.K. Johansen, C. and Rego, T. J. Eds.). pp. 3-13. ICRISAT, Patancheru, Andhra Pradesh.

Lichtenthaler HK and Wellburn AR 1983. Determination of chlorophyll a, b of leaf extract in different solvents. Biochem. Soc. Trans. 11: 591-597.

Liscum E and Reed JW 2002. Genetics of AUX/IAA and ARF action in plant growth and development. Plant Mol. Biol. 49: 387-400.

McVicar R, McCall P, Brenzil C, Hartley S, Panchuk K, Mooleki P, Vandenberg A and Banniza S 2010. Lentils in Saskatchewan. Fact Sheet. Saskatchewan Ministry of Agriculture, Canada.

Pandey SN and Gautam S 2009. Effects of zinc supply on its uptake, growth and biochemical constituents in lentil. Indian J. Plant Physiol. 14: 67-70.

Ramakrishna A, Gowda CLL and Johansen C 2000. Management factors affecting legumes production in the Indo-Gangetic Plain. In: Legumes in rice and wheat cropping systems of the Indo-Gangetic Plain constraints and opportunities. (In: Johansen, C. Duxbury, J.M. Virmani, S.M. Gowda, C.L.L. Eds.). pp. 156-165. ICRISAT, Patancheru, Andhra Pradesh.

Reid DE, Ferguson BJ, Hayashi S, Lin YH and Gresshoff PM 2011. Molecular mechanisms controlling legume autoregulation of nodulation. Ann. Bot. 108: 789-795.

Singh AK, Meena MK and Bharati RC 2011. Sulphur and zinc nutrient management in rice lentil cropping system international conference on Life Science Research for Rural and Agricultural Development, 2729 December, 2011, CPRS Patna (Bihar). pp. 66-67.

Singh AK and Bhatt BP2013. Effects of foliar application of zinc on growth and seed yield of late-sown lentil. Indian J. Agril. Sci. 83: 622-626.

Somani LL 2008. Micronutrients for soil and plant health. Agrotech Publishing Academy. pp. 14-74.

Thiyagarajan TM, Backiyavathy MR and Savithri P 2003. Nutrient management for pulses - A Review. Agric. Res. 24: 40-48. 